\title{
Mind simulation model; an effective treatment to decreasing dissociative experiences caused by traumatic events in adult with stuttering disorder
}

\author{
Akram Hosseinzadeh ${ }^{1}$, Mohammad Ehsan Taghizadeh ${ }^{2}$ \\ 1-MA in Clinical Psychology, Department of Psychology, Islamic Azad University, Roodehen Branch, Tehran, Iran \\ (Corresponding Author)._E-mail: ahasanzadeh.psy1398@yahoo.com \\ 2- Associate Professor, Department of Psychology, Payam-e-Noor University, Tehran, Iran.
}

Received: 27/12/2019

Accepted: 28/01/2020

\begin{abstract}
Introduction: Stuttering can begin with the experience of traumatic event and the stress it causes. Mind simulation model is one of the promising treatments for stuttering and its associated problems.

Aim: This study aimed to investigate the effectiveness of mind simulation model on decreasing dissociative experiences caused by traumatic events in adult with stuttering disorder.

Method: This was a quasi-experimental study with a pre-test/ post-test design and a control group. The study population included all stutterers who referred to the Tavanmandsazan-e-Zehn Clinic in 2018-2019. Among them, the number of 30 stuttering 18- 45 years old men who had experienced a traumatic event were selected through available sampling method and put randomly into the experimental and control groups. After measuring basic levels of dissociative experiences of all participants using dissociative experiences scale (Bernstein, 1993), the experimental group received mind simulation therapy, while the control group received no intervention. Finally, both groups completed the post-test.

Results: Results of MANCOVA analysis showed that mind simulation model could significantly reduce dissociative experiences (including dissociative amnesia 9 depersonalization/derealisation, and absorption/imaginative) $(\mathrm{p}<0.01)$ in participants whose their stuttering were caused by experiencing traumatic events compared to the control group.

Conclusion: Given these findings, it can be claimed that the use of this new method can help the therapists in the effective treatment of stuttering and its associated problems by mind enabling of the patients.
\end{abstract}

Keywords: Dissociative experiences, Mind simulation model, Stuttering, Traumatic events

How to cite this article: Hosseinzadeh A, Taghizadeh M E. Mind simulation model; an effective treatment to decreasing dissociative experiences caused by traumatic events in adult with stuttering disorder. Shenakht Journal of Psychology and Psychiatry. $2020 ; 7$ (1): $90-102$. URL: http://shenakht.muk.ac.ir/article-1-737-fa.pdf

Copyright $\odot 2018$ the Author (s). Published by Kurdistan University of Medical Sciences. This is an open access article distributed under the terms of the Creative Commons Attribution-Non Commercial License 4.0 (CCBY-NC), where it is permissible to download, share, remix, transform, and buildup the work provided it is properly cited. The work cannot be used commercially without permission from the journal. 


\title{
مدل شبيهسازى ذهن؛ درمانى مؤثر در كاهش تجارب تجزيهاى ناشى از حوادث آسيبزا در افر اد مبتلا به لكنت زبان
}

\author{
اكرم حسين زاده'، محمد احسان تقى زاده׳ \\ ا.كارشناسى ارشد روان شناسى بالينى، گروه روان شناسى، دانشكاه آزاد اسلامى، واحد رودهن، تهران، ايران (مولف مسئول). \\ ايميل: ahasanzadeh.psy1398@yahoo.com \\ r. دانشيار، گُروه روان شناسى، دانشكاه يِيام نور، واحد تهران جنوب، تهران، ايران.
}

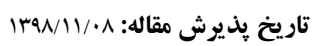

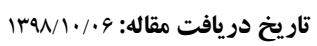

جكيده مقدمه: لكنت زبان مى تو اند به دنبال تجربه حوادث آسيبزاو استرس ناشى از آن شروع شود و علائم تجزيهاى را به همراه داشته باشد.

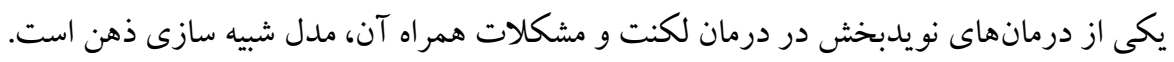
هدف: هدف از ئزوهش حاضر، مطالعه اثربخشى مدل شبيهسازى ذهن بر كاهش تجارب تجزيهاى ناشى از حوادث آسيبزا در افراد مبتلا به لكنت بود.

روش: اين يُوهش از نوع نيمه آزمايشى با طرح ييش آزمون-بس آزمون و گروه كنترل بود. جامعه يُزوهش شامل تمامى افراد مبتلابه

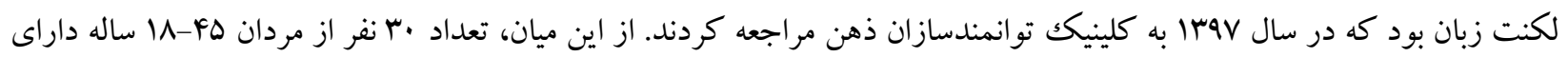

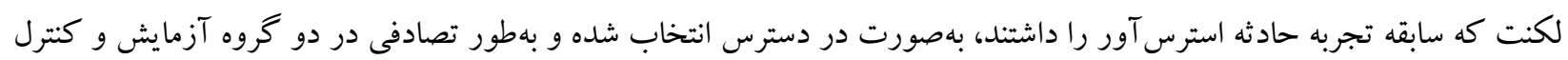

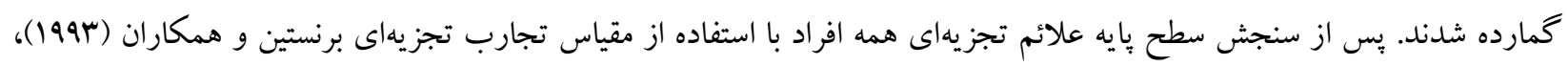

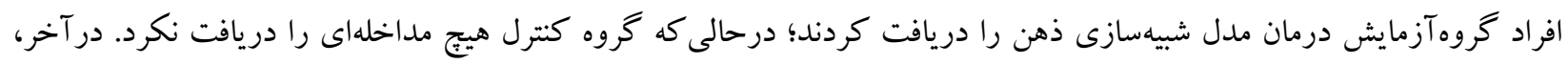

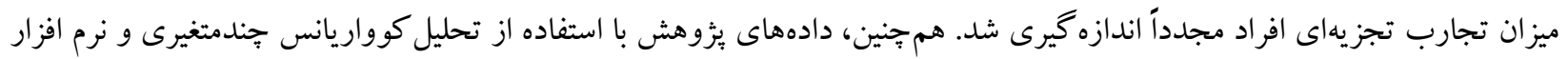
س بr SPSS تجزيه و تحليل شدند. يافتهها: نتايج نشان داد كه مدل شبيهازى ذهن در مقايسه با گروه كنترل، بر كاهش تجارب تجزيهاى (فراموشىتجزيهاى،

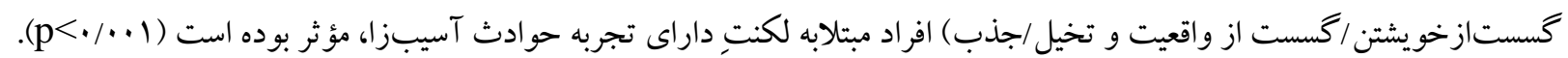
نتيجه كيرى: با توجه به نتايج بدست آمده مىتوان اذعان داشت كه استفاده از اين روش نوين مىتواند با توانمندسازى ذهن مبتلايان،

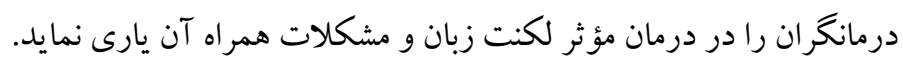
كليد وازهها: تجارب تجزيهاى، حوادث آسيبزا، لكنتزبان، مدل شبيهسازى ذهن 
از حالت خفيف فاصله گرفته و تشديد مىيابد. تمامى

سامانهاى شناختى و رفتارى ما ازجمله زبان تا سن دهالكى شكل مى گيرند و لكنت زبان عمدتاً در دوران رهان كودكى ايجاد مىشود، يعنى زمانى كه هنوز سامانه

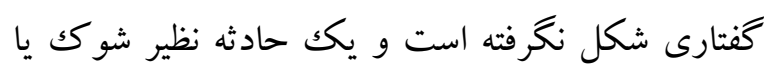
ترس و غيره مىتواند روى گفتار تأثير گذار باشد. هم جنين، به دليل عدم تكامل ذهن و سامانه كفتارى، در برخى كود كان عادتهاى بد كفتارى يا تقليد و تعامل با

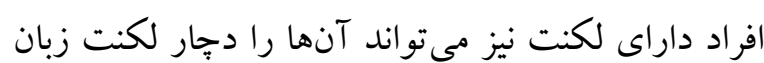
كند (تقىزاده و بيگدلى شاملو، 19

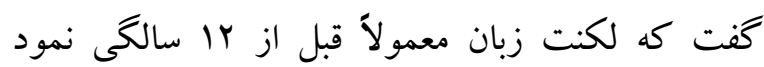
مىيابد. هم جنين، دوره اوج اين اختلال بين سنين ب تا ه/

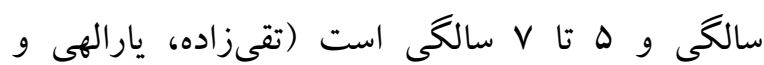

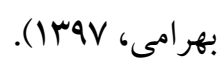
از سوى ديخر، برخى بثزوهش ها ارتباط بين لكنت زبان و و

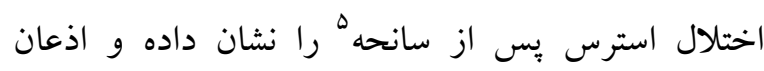
دارندكه لكنت زبان مىتواند به دنبال حوادث آسيبزا و وسته تروماتيك و ترس و وحشت ناشى از آن شروع شود (بيل

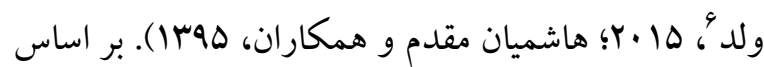
ينجمين راهنماى تشخيصى و آمارى اختلالات روانى، اختلال استرس بس از سانحه مجموعهاى از علائم است كه بر اثر تجربه حوادث آسيبزاى زندگى (مانند مواجها با مرك واقعى يا تهديد به مرگك، آسيب شديد يا تجاوز

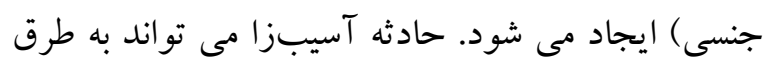
كوناكونى مجدداً تجربه شود و با علائم تجزيهاى همراه

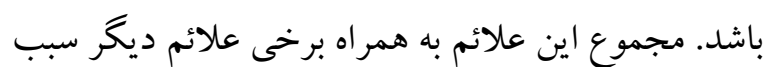

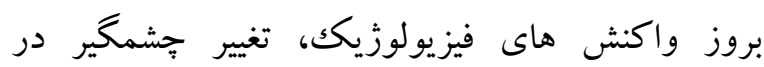
انخيختخى و واكنش يذيرى، تغييرات شناختى منفى و و

5 - Post-Traumatic Stress Disorder (PTSD)

${ }^{6}$ - Henny-Annie Bijleveld
زبان، از مؤثرترين ابزارها براى برقرارى روابط و در واقع، نوع عالى و مشتركى رفتار اجتماعى است (احدى و همكاران، (1) إ). گفتار، از نمونههاى عينى و قابل شنيدن زبان است كه در ايجاد ارتباط افراد با يكديخر از اهميت زيادى برخوردار است. كفتار و زبان هر يكك ممكن است جداكانه يا با هم به دلايل مختلف دجرار آسيبهايى به درجات گوناگون شوند و مسير ارتباطى اصلى انسان را

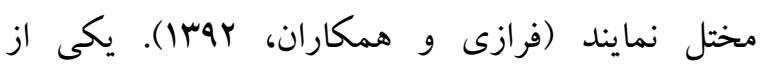
مهمترين و متداولترين اختلالات تكلمى، اختلال لكنت

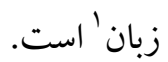

بر اساس بنجمين راهنماى تشخيصى و آمارى اختلالات

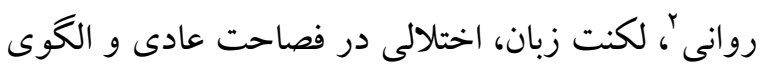
زمانى كفتار است كه فرد را در كسب مهارتهاى زبانى

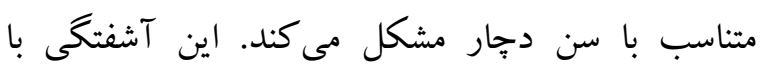

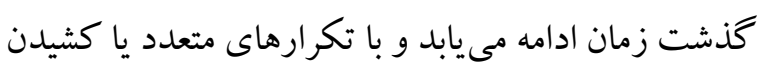
اصوات و هجاها و ساير انواع عدم فصاحت كلامى مشخص مىشود؛ شدت آن از موقعيتى به موقعيت ديخر فرق مى كند و در مواقعى كه فشار و هيجان وجود دارد بيشتر است و با بيشرفت تحصيلى و شغلى يا ارتباطات اجتماعى فرد تداخل دارد. (انجمن روانيزشكى آمريكآ، rا •Y). شيوع لكنت زبان بين سنين كودكى و نوجوانى حدود r-1 درصد است كه نسبت ابتلاى يسران به

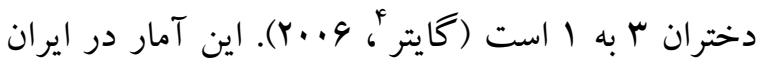
نيز تأييد شده است (زمانى و لطيفى، ·ara). لكنت زبان يكك نوع اختلال در سامانه كفتارى انسان است كه توسط عوامل مختلفى ايجاد مىشود و رفتهرفته

\footnotetext{
1- Stuttering

2- Diagnostic and Statistical Manual of Mental Disorders (DSM-5)

3 - American Psychiatric Association (APA)

4- Guitar
} 
يكى از درمانهاى جديد و نويدبخش در درمان مؤثر و بدون باز گشت لكنت زبان، مدل شبيهسازى ذهن تقىز ادهاه

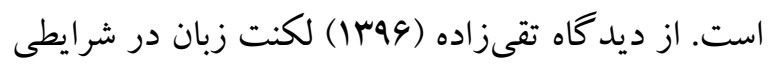
كه جسم آسيب نديده باشد (مثل ضربه، بيمارى جسمى و آسيب ديدن اعضاى كفتارى)، مسئلهاى كاملاً ذهنى و و روانى است. افراد دار ایى لكنت نمىتو انند با نكاه كردن به

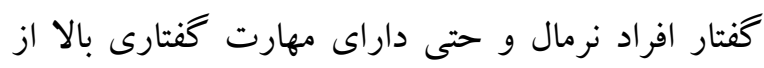
آنها بياموزند. طبق اين ديدگاه، علت شكست درمانهاى

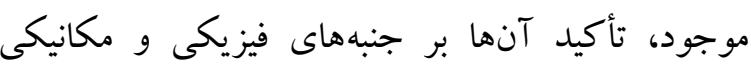
كفتار است. حال براى ايجاد مهارتهاى گُقتارى بايد

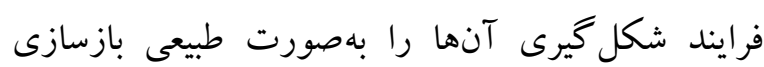

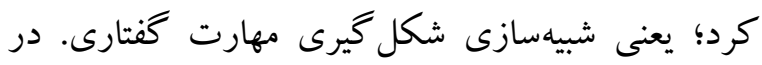

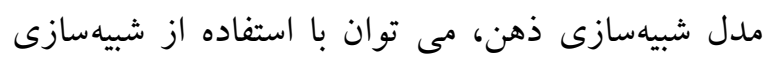
ذهن و زبان برنامهنويسى ذهن، فرايند طبيعى شكل گيرى

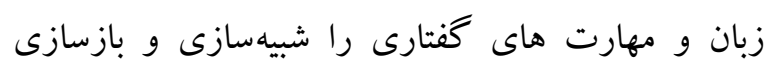
كرده و با طراحى برنامه آموزشى - درمانى متناسب، آنها

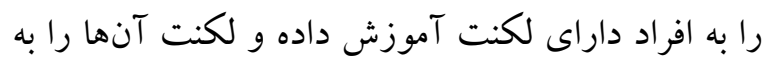
شكل قطعى درمان كرد (تقىزاده و بيخدلى شاملو،

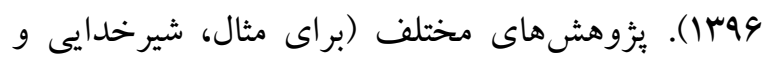
تقىزاده، وهبا؛ صانعى و تقىزاده، وهبا! تقىزاده،

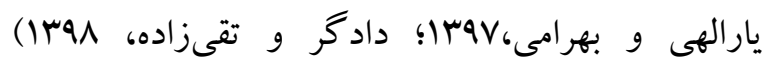
كار آمدى اين مدل را در درمان مشكلات همراه با لكني نشان دادهاند.

به اين ترتيب، با توجه به نقش حوادث آسيبزا و

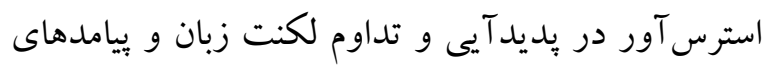
فردى و بين فردى آن و هم جنين با توجه به اينكه بسيارى از درمانهاى كنونى بهطور كامل اثربخش نبوده و يا نتايج درمانى آنها بس از مدتى باز گشت مى كند (تقىزاده و

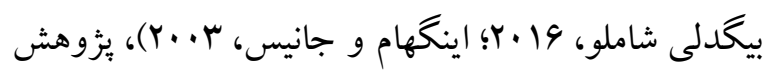

ناراحتى شديد روان شناختى و در نتيجه، اجتناب مداوم فرد از محرككهاى مربوط به حادثه آسيبزا شود (انجمن روان شناسى آمريكا، سا. (Y). افرادى كه لكنت زبان آنها به دنبال تجربه حوادث آسيبزا ايجاد شده است، ممكن است مكرراً حادثه مذكور را در طول روز و حتى در خلال رؤيا تجربه كنند و نيز علائم تجزيهاى را نشان دهند كه از جند ثانيه تا جندين ساعت و حتى روزها به طول انجامد و طى آن جزئياتى از حادثه دوباره زنده مىشود و فرد جنان رفتار مى كند كه كويى حادثه در آن لحظه در حال وقوع است. در اين افراد در واكنش به عامل استرسزا، تجربه مستمر يا مكرر يكى از حالات زير احساس مىشود: 1- گسست

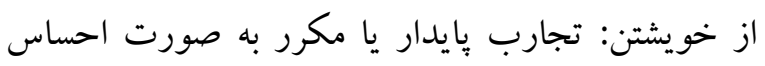
جدا شدن از روندهاى ذهنى يا بدن خود، جنان كه كويى فرد خود را از خارج مى نخرد و ب- كسست از واقعيت: تجارب بايدار يا راجعه به صورت احساس غيرواقعى

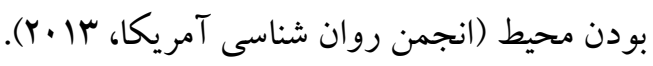
امروزه اقدامات مختلفى براى درمان افراد داراى اختلال لكنت انجام مى گيرد (مانند گفتاردرمانى، دارودرمانى، درمانهاى شناختى - رفتارى). باوجوداين، تلاشهاى صورت گرفته در درمان لكنت عمدتاً موفقيت آميز نبوده و يا نتايج درمان يس از جندى باز گشت كرده است. بر

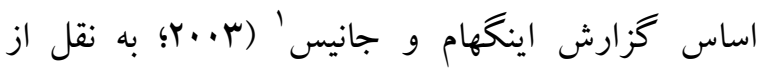
تقىزاده، يارالهى و بهرامى، لوسM (I)، انتقال مهارتهاى نظاممند روانى كفتار در طول جلسات درمانى مفيد بوده، اما حفظ و تداوم روانى ايجاد شده براى بلندمدت به سبب قطع شدن محرك (الكوى كفتارى ارائه شده) بهندرت امكانيذير است. 
ه) به جز لكنت، تجارب تجزيهاى ناشى از استرس بِ از

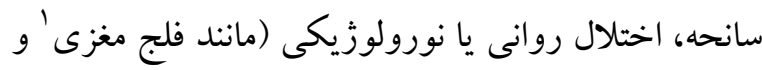
سابقه سكته شديد مغزى) ديخرى نداشته باشند.

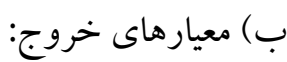
() لكنت بسيار خفيف و يا داشتن سابقه لكنت زبان فيزيكى

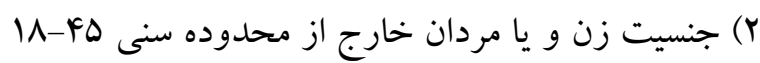

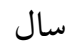
ץ) نداشتن سابقه تروما و علائم تجزيهاى F) عقبماندگى ذهنى يا عدم هوشيارى لازم

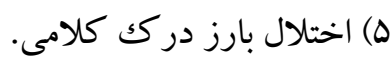
9) سابقه بيمارى روانى به جز لكنت، تجارب تجزيهاى ناشى از استرس بِ از سانحه؛ و يا ابتلا به اختلالات

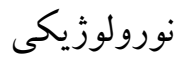

\section{ابز ار}

در اين بثوهش بهمنظور جمع آورى دادهها و اجراى يزوهش از ابزارهاى زير استفاده شد:

مقياس تجارب تجزيهاع (DES-II)

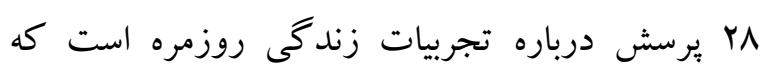
توسط برنستين 'و همكاران (س991) طراحى شده است. مقياس تجارب تجزيه اى از نظر تهيه كنند كانش "يكك

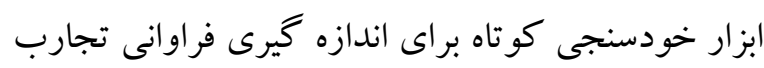
تجزيه اى است). اين مقياس به عنوان ابزارى معتبر و وِايا جهت كمى سازى تجارب تجزيهاى طراحى شده و توسعه يافته است. شركت كنند گان گز ارش مى دهند كه تجارب خاص با موارد رخ داده اغلب جِكونه توصيف
حاضر باهدف بررسى تأثير مدل شبيهسازى ذهن برگرفته از بِكيج آموزشى- درمانى تقىزاده در درمان علائم تجزيهاى در افراد مبتلابه لكنت زبان انجام شد.

روش يزوهش حاضر از نوع نيمه آزمايشى با طرح بيش آزمون-

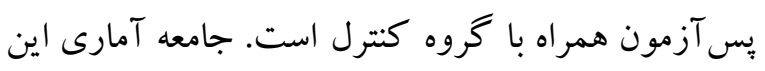

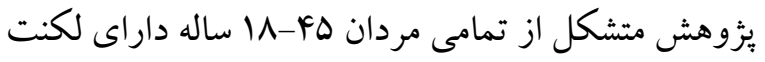

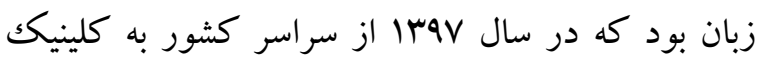
توانمندسازان ذهن واقع در شهر تهران مراجعه نمودند. نمونه گيرى بثوهش حاضر بهصورت در دسترس بود. به اين منظور، با توجه به اينكه در طرحهاى آزمايشى تعداد

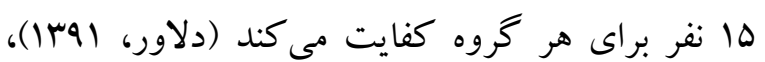

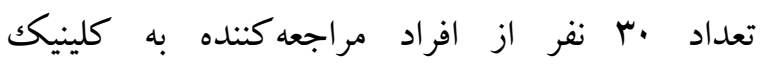
توانمندسازان ذهن كه توسط ارزيابىهاى متخصص، لكنت متوسط تا خيلى شديد داشتند، يس از بررسى معيارهاى ورود به بزوهش و جلب رضايت آكاهانه، انتخاب شده و بهطور تصادفى در دو گروه آزمايش (درمان) و كنترل (هر گروه ها نفر) جايكزين شدند. لازم به ذكر است، معيارهاى ورود و خروج افراد به اين شرح

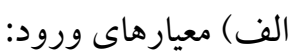

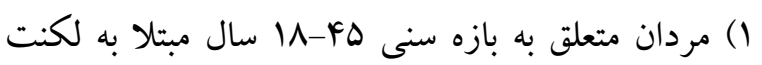
زبان (با منشأ روانى) متوسط تا خيلى شديد r) داشتن بيشينه تروما و علائم تجزيهاى

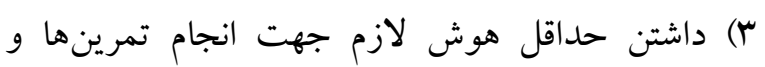
مهارتها (F) عدم وجود اختلال بارز در درك كلامى عهى 
آزمون بين V9/ • تا 99/• است. محدوده ضريب دو نيمه كردن را بين rA/· تا سه/• گزارش شده است (بروس و و

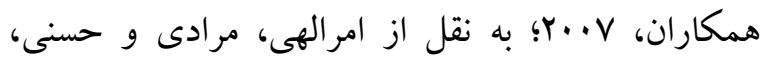
ه9r1). هم جنين، در يُزوهش سجادى و دهقانى زاده (هوسا) بر روى نسخه فارسى مقياس تجارب تجزيهاى، آلفاى كرونباخ اين مقياس به/ • محاسبه شد. يروتكل دومان (ملدل شبيهسازى ذهن بركرفته از يكيج درمانى - آموزشى لكنت زبان تقىزاده): در جلسه اول بعد از آشنايى با تعداد جلسات و روند درمان و آشنايى بيشتر با لكنت و درمانهاى رايج و ناموفق، افراد در بر برد بهصورت اختصاصى و گروهى با درمان نوين شبيهسازى ذهن و موفقيت اين درمان در رفع لكنت مبتلايان آشنا مىشوند. از جلسه دوم تا جلسه دوازده، در ابتداى هر جلسه ميزان بيشرفت مراجع بر آورد شده و تكاليف جلسه قبل مرور مىشد. يس از اجراى روند اختصاصى هر

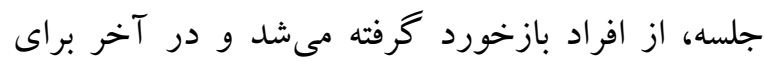

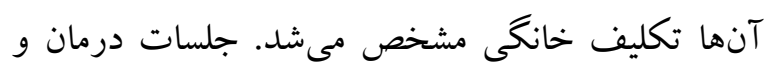
محتواى هر جلسه در جدول زير آمده است:
مىشوند. براى مثال برخى افراد گاهى اوقات موقع گوش كردن به حرف كسى ناگهان متوجه مى شوند كه تمام يا قسمتى از صحبت طرف مقابل را نشنيده اند. در سؤالات كَته مى شود با انتخاب عدد مناسب نشان دهيد كه جند درصد مواقع جنين جيزى براى شما اتفاق افتاده است؟ افراد در محدوده · (هركز) تا ...1 (هميشه) مشخص مى كنند كه اغلب به جه ميز ان تجارب خاص برايشان رخ مى دهد (امرالهى، مرادى و حسنى، هوسا). اين مقياس

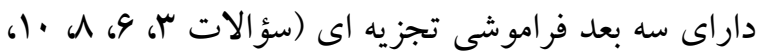

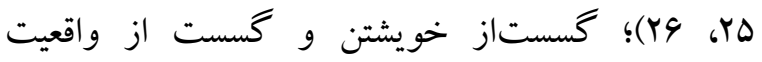

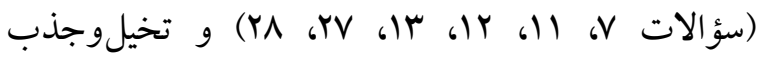

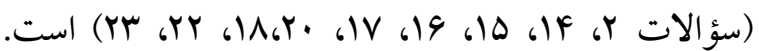
نمره هريكك از ابعاد با تقسيم مواد هر بعد بر نمره كل حاصل مى شود و در آخر يكى نمره كلى نيز محاسبه

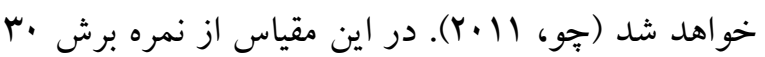
استفاده مى شود (برنستين و همكاران، س991؛ به نقل از

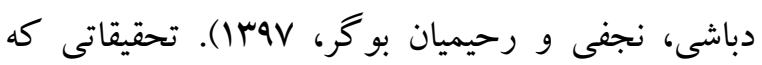
اعتبار و روايى اين ابزار را نشان مى دهد داراى ثبات

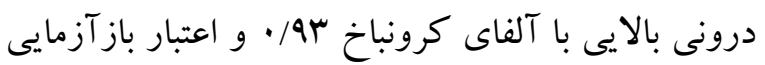

\begin{tabular}{|c|c|}
\hline محتوا & 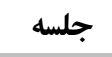 \\
\hline كد كذارى -تصوير سازى ذهنى & جلسه 1 \\
\hline ريتميك كششى -ريتميكك جرخشى & 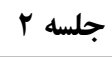 \\
\hline حالت خطى در كلام -تكنيك نيمهباز ذهنى - كفتارى & 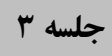 \\
\hline حالت رها در كلام -تمرين بيجج افكار & جلسه ع \\
\hline كنترل هيجان كلامى -مديريت بر استرس & 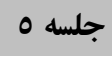 \\
\hline درمان تيك سروصورت -درمان وسواس فكرى و كلامى & جلسه 7 \\
\hline تقويت اعتمادبهنفس -ياككسازى ذهنى & 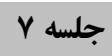 \\
\hline تمرين و تكنيكك تأكيد و قدرت -تمرين دورانى & جلسه 1 \\
\hline هماهنخى ذهن و بدن -كنترل هيجان در كفتار & جلسه 9 \\
\hline
\end{tabular}




\begin{tabular}{|c|c|}
\hline اصلاح ريتم گفتارى -حذف فشارهاى فيزيكى در كفتار & جلسه || \\
\hline ييوستگى در كلام -جمعبندى و خلاصهسازى درمان -دادن راهكارهاى لازم آموزشح & 118 \\
\hline
\end{tabular}

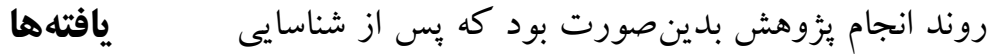

در اين قسمت ابتدا يافتهاى مربوط به متغيرهاى جمعيت

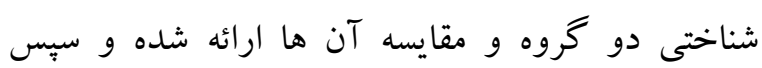
يافتهاى توصيفى و استنباطى در مورد متغيرهاى اصلى يزّوهش مورد بحث قرار كفته است. هر كدام از كروهها شامل ها نفر بودند. ميانگين سنى (انحراف استاندارد)

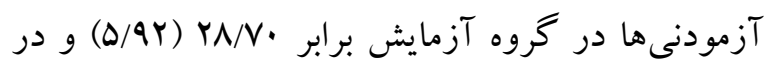

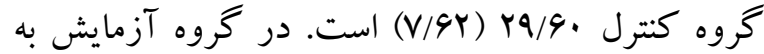
ترتيب سو V V نفر مجرد و متأهل بودند؛ در گروه كنترل نيز تعداد ها آنان مجرد و ها نفر متأهل بودند. هم جنين، در مورد سطح تحصيلات نمونه ئزوهش بايد كفت كه در

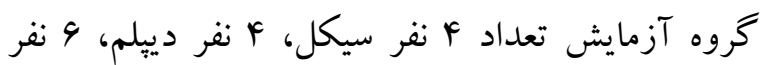
كارشناسى و r نفر كارشناسى ارشد بودند. در كروه لعره

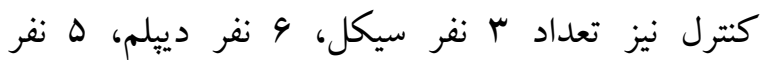
كارشناسى و ا نفر كارشناسى ارشد بودند. لازم به ذكر است كه مقايسه متغيرهاى توصيفى يادشده، تفاوت معنادارى را بين دو گروه نشان نداد. علاوه بر اين، نمرات مربوط به ميزان تجربه علائم تجزيهاى افراد دو كروه يِيش از شروع درمان

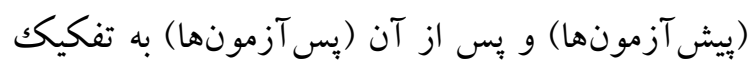
كروهها و با توجه به ميانگين و انحراف استاندارد در جدول شماره Y آورده شده است. افراد مبتلا به لكنت -كه بر اساس مصاحبه و ارزيابى متخصص اين حوزه، مبتلا به لكنت زبان تشخيص داده شدند- و انتخاب نمونه با توجه به معيارهاى ورود و خروج، جهت كنترل نمرات خط بايه شركت كنندگان، هر دو گروه به تكميل مقياس تجارب تجزيهاى برداختند

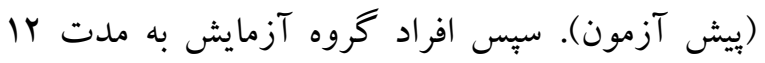
جلسه فردى - گروهى (هفتهاى يكك جلسه) با استفاده از مدل درمانى شبيهسازى ذهن تحت درمان قرار گرفتند و افراد گروه كنترل تا زمان انجام يس آزمونها در ليست انتظار ماندند. در آخر، به منظور فراهم آوردن امكان مقايسه كروه هاى و تعيين اثربخشى مدل درمانى شبيهسازى ذهن، بار ديخر مقياس تجارب تجزيهاى در هر

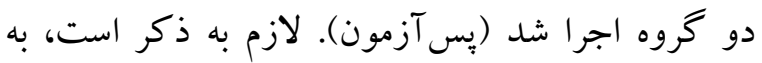

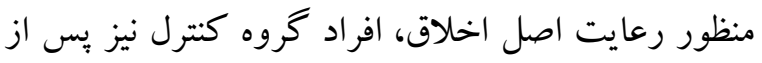
اتمام يزوهش درمان شدند. لازم به ذكر است تجزيهوتحليل دادهها با استفاده از شاخصهاى آمار توصيفى (ميانخين، انحراف استاندارد) و آمار استباطى (تحليل كوواريانس جندمتغيرى (مانكووا)) جهت كنترل نمرات بيش آزمون گروههاى آزمايش و و كنترل و مقايسه نمرات بس آزمون دو گروه با كمكك لمك

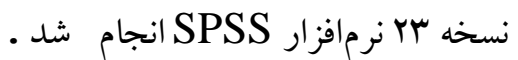

\begin{tabular}{|c|c|c|c|c|}
\hline انحراف معيار & ميانكين & متغير & آزمون & تروه \\
\hline .194 & $r / \Upsilon \Lambda$ & فراموشى تجزيه اى & \multirow{3}{*}{ ي يش آزمون } & \multirow[t]{3}{*}{ كروه آزمايش } \\
\hline .194 & $r / \cdot \cdot$ & گسست از خويشتن و گسست از واقعيت & & \\
\hline$\cdot / \mathrm{rr}$ & $r / r$ & تخيلوجذب & & \\
\hline
\end{tabular}




\begin{tabular}{|c|c|c|c|c|}
\hline$\cdot / \mathrm{TV}$ & $r / \bullet \Delta$ & فراموشى تجزيه اى & 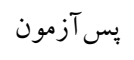 & \\
\hline.$/ 01$ & $1 / N$ & گُست از خو يشتن و گسست از واقعيت & & \\
\hline$\cdot / 4 \pi$ & 1/90 & تخيلوجذب & & \\
\hline$\cdot / \Delta \Delta$ & $r / \Lambda$. & فراموشى تجزيه اى & \multirow[t]{3}{*}{ بيش آزمون } & \multirow[t]{6}{*}{ كروه كنترل } \\
\hline$\cdot / N$ & r/Aq & گگست از خويشتن و گسست از واقعيت & & \\
\hline.$/ 9 V$ & $r / \wedge q$ & تخيلوجذب & & \\
\hline$\cdot / 41$ & $r / 4 r$ & فراموشى تجزيه اى & \multirow[t]{3}{*}{ پس آزمون } & \\
\hline.$/ \Delta r$ & $r / \cdot v$ & گُست از خو يشتن و گسست از واقعيت & & \\
\hline$\cdot / \mathrm{NF}^{\mathrm{F}}$ & $r / F q$ & تخيلوجذب & & \\
\hline
\end{tabular}

براى بررسى اين فرض از آزمون همخنى واريانسهاى

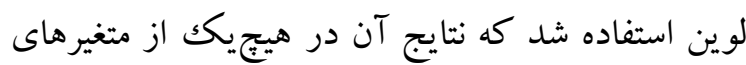

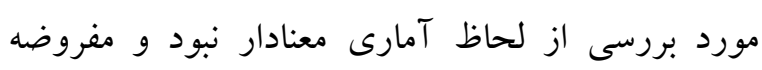

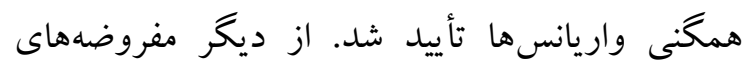
آزمون تحليل كوواريانس جند متغيرى، همسانى

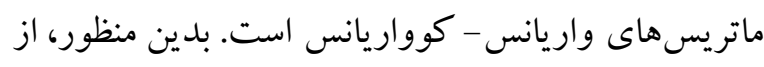
آزمون باكس ' استفاده شده است. با توجه به آمارههاى

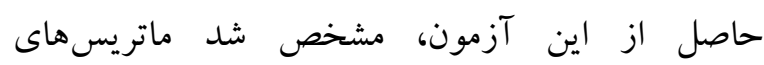
واريانس - كوواريانسها همگن هستند. علاوه بر اين، آرمون، ديخر مفروضه مهم تحليل كوواريانس جند متغيرى، همخنى ضرايب رگرسيون (همخنى شيبها) است. لازم به ذكر است كه آزمون همخنى ضرايب رگرسيون از طريق تعامل بيش آزمونها و متغير مستقل (روش درمان) در مرحله يّآزمون مورد بررسى قرار گرفت. نتايج نشان داد تعامل اين بيش آزمونها با متغير مستقل معنادار

$$
\text { نبوده و ضرايب ركرسيون همخن بود. }
$$

بهاين ترتيب، با توجه به بررسى مفروضه هاى آزمون تحليل كوواريانس جندمتغيرى و تأييد آنها، در ادامه نتايج مربوط به تأثير درمان مبتنى بر مدل شبيهسازى ذهن بر كاهش تجارب تجزيهاى (شامل فراموشى تجزيهاى،

\footnotetext{
${ }^{1}$ - Box's Test of Equality of Covariance Matrices
}

همان كونه كه مشاهده مىشود، نمرات يِش آزمون افراد دو گرووه در متغيرهاى بثزوهش تا حدودى مشابه است و

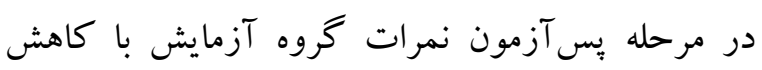

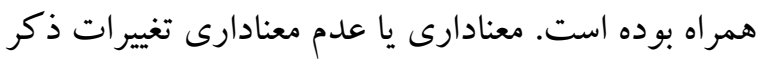
شده در قسمت بعدى بررسى شده است. با توجه به طرح يثوهش حاضر كه از نوع بيش آزمون و

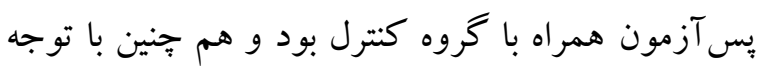
به وجود سه خرده مقياس، براى تحليل دادهها و بهمنظور كنترل اثر ييش آزمونها از روش تحليل كوواريانس جند بهد بردي متغيرى (مانكووا) استفاده شد. در اين نوع تحليل بايد شرطهاى زير رعايت گردد تا بتوان به نتايج بهدست آمده اطمينان كرد: يكى از مفروضههاى آزمون تحليل كوواريانس جند مدهد متغيرى، نرمال بودن توزيع متغيرهاى وابسته است. با توجه إنهائ

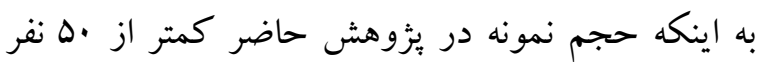
بود، جهت بررسى بيشفرض مذكور از آزمون شاييروويلك استفاده شد كه نتايج حاصل از آن، فرض صفر يعنى نرمال بودن متغيرهاى وابسته را تأييد كرد. هم جنين، در آزمون مانكووا فرض بر اين است كه واريانس نمرههاى خام در گروههايى كه قرار است مورد تحليل قرار گيرند، تفاوت آمارى معنادارى با يكديخر ندارند. 
كوواريانس جِندمتغيرى آورده شده است (جدول ؟).

كست از خويشتن/گسست از واقعيت و تخيل/جذب) در افراد مبتلابه لكنت با استفاده از آزمون تحليل

جدول ب نتايج آزمون مانكووا مربوط به تأثير مدل شبيهسازى ذهن بر تجارب تجزيهاى در افر اد مبتلا به لكنت با سابقه حوادث تروماتيك ماتيك

\begin{tabular}{|c|c|c|c|c|c|c|c|}
\hline معنادارى سطح & $\mathbf{F}$ & مجذانكين & آزادى & مجذورات & منبع تغييرات & متغير & \\
\hline$\cdot / \cdots$, & $r Y / \Delta I$ & $18 / M$ & 1 & $10 / M$ & كروه & \multirow[t]{2}{*}{ فراموشى تجزيهاى } & \multirow{6}{*}{3} \\
\hline & & $\cdot / \cdot v$ & TV & $1 / 9 F$ & خطا & & \\
\hline.$/ . \cdot 1$ & $19 \cdot / \mathrm{VV}$ & $F \Delta \Lambda / F \Delta$ & 1 & $\mid \Delta N / F \Delta$ & كروه & \multirow{4}{*}{ كسست از خويشتن و } & \\
\hline & & $\cdot / \mu F$ & rV & N/৭9 & خطا & & \\
\hline \multirow[t]{2}{*}{.$/ \cdots 1$} & $19 \cdot / \Delta 9$ & $\Delta / Q F$ & 1 & $\Delta / Q F$ & كروه & & \\
\hline & & D & TV & 91.4 & خطا & & \\
\hline
\end{tabular}

گَست از خويشتن و گسست از واقعيت در افراد مبتلابه لكنت زبان كه سابقه تجربه حادثه آسيبزا در زندكى شان داشتند، مؤثر بوده است. اين يافتها با نتايج

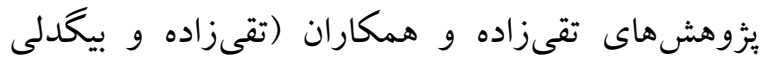

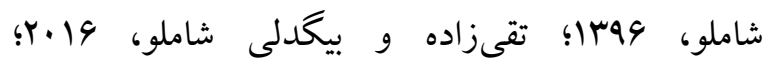
شيرخدايى و تقىزاده، وهبا؛ صانعى و تقىزاده، وهMا؛ تقىزاده، يارالهى و بهرامى، Vqبا! خندان و تقىزاده،

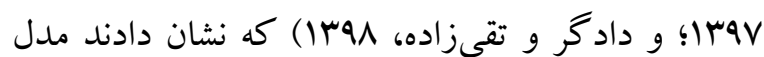
شبيهسازى ذهن مىتواند در درمان لكنت زبان و و مشكلات همر اه آن مؤثر افتد، همخوان است. همسو با نتايج بثزوهشهاى مبتنى بر دانش شبيهسازى ذهن در درمان لكنت، مطالعات ديخر نيز اثربخشى انواع شبيهسازى را در حيطههاى مختلف نشان دادهاند. براى

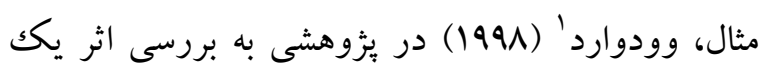
شبيهساز كامييوترى بر افزايش مهارت حل مسئله و

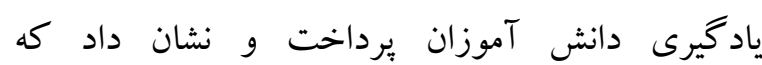

1. Woodward
با توجه به جدول فوق، بس از كنترل اثر بيش آزمونها با استفاده از روش مانكووا، بين دو گروه درمان و كنترل در مرحله پِس آزمون در نمرات خرده مقياسهاى علائم

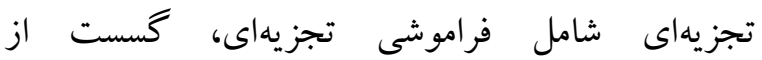
خويشتن/كسست از واقعيت و تخيل/جذب اختلاف معنادارى وجود دارد. با توجه به ميانگين نمرات كسبشده كه بيشتر اشاره شد (جدول Y)، مشخص مىشود كه مدل شبيهسازى ذهن در مقايسه با گروه

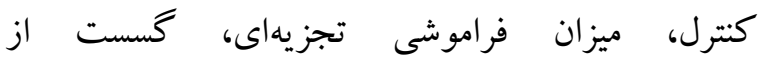
خويشتن/گسست از واقعيت و تخيل/جذب در افراد مبتلابه لكنت زبان با سابقه تجربه حادثه آسيبزا را بهطور

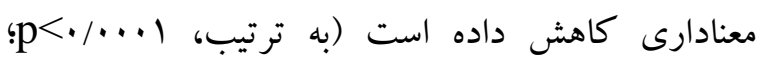
$.(\mathrm{p}<\cdot / \cdots), \mathrm{p}<\cdot / \cdots)$

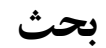
با توجه به نتايج بالا مىتوان كفت كه مدل شبيهسازى ذهن بر كاهش ميزان تجربه مجدد خاطرات آسيبزا، 
سختافزار و نرمافزار دارد. مغز و بدن بعد سختافزارى ما و ذهن بعد نرمافزارى ما است. براى كنترل و ايجاد تغييرات در مغز و بدن بايد از ذهن شروع كرد؛ جايى كه فرمانها و دستورات را ساخته و به مغز ارسال مى كند و مغز هم با انتقال ييامهاى عصبى به اندامها حر كات و ونر رفتارهاى ما را مىسازد. در اين مدل با استفاده از زبان ذهن، برنامه ذهنى موجود فرد مطالعه شده و اشكالات آن مان به دست مى آيد و با طراحى يك برنامه جديد و كامل و

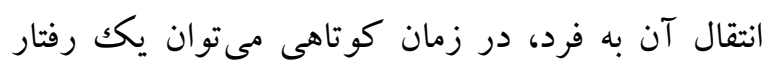
بيجيده را در فرد ايجاد كرده كه به حر كت موردنظر ختم شود. از ديد كاه مدل شبيه سازى ذهن، ريشه لكنت اختلال در ريتم، كاركرد گفتارى ذهن و هم جنين اختلال در

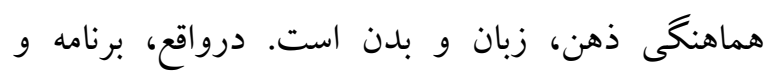
دستورات غلط ذهنى فرد باعث تغييرات در كاركرد مغز مىشود و فرد بهجاى استفاده از حنجره و كنترل صحيح آن، به قسمتهاى ديخرى (مانند ماهيجههاى حلقى، عضلات صورت، لبها، فكك و غيره) نيرو وارد مى كند. حال بايد كارى كرد كه نيروها و كنترل از قسمتهاى ديخر برداشتهشده و فقط تمركز روى حنجره ايجاد شود؛ بنابراين، با تغيير برنامه ذهنى فرد به شكل طبيعى، سبك

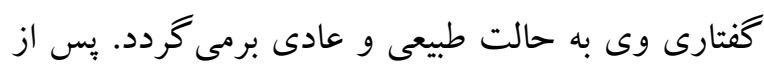

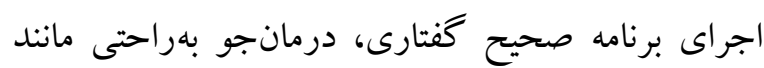

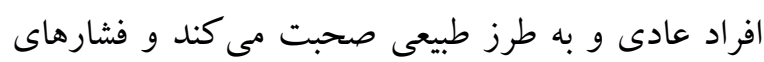

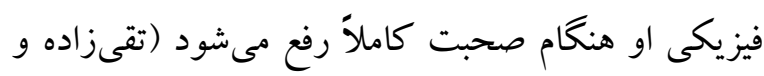

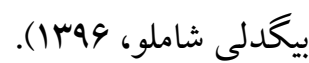
علاوه بر اين، يافتهاى حاضر با يزوهشها حوزه نوروساينس نيز همخوان است. تا جند دهه قبل تصور مىشد كه ارتباطهاى سينايسى در مغز پِّتانداران بزرگكسال نسبتاً ثابتاند و تغيير در مغز در حال بير شدن
شبيهسازها نسبت به روش معمول داراى برترى معنادارى در آموزش مهارت حل مسئله و مفاهيم و حقايق اساسى به دانش آموزان هستند. هم جنين، خليلى شرفه، ياكدامن و صدق يور (MMM) در مطالعهاى نشان دادند كه شبيهسازى ذهنى با توجه به كنترل عامل هوش، به بهبود عملكرد

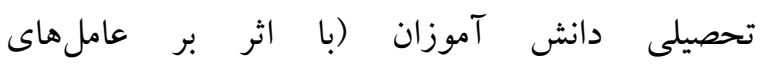
خود كار آمدى، برنامهريزى و انخيزش) مى انجامد. بِارسا و لهوري

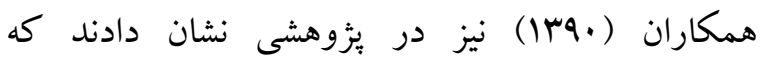
روشهاى شبيه سازى فر آوردهاى و هم زمان مىتوانند تأثير معنادارى بر عملكرد تحصيلى و حافظه دانش آموزان داشته باشند

در تبين نتايج به دست آمده يُزوهش حاضر مىتوان

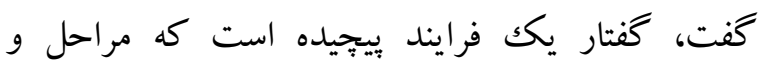
كامهايى دارد و مانند تمامى رفتارها داراى الخوريتم مشخص است. عملكرد گفتار بر اساس الخوريتم محركهاى بيرونى و درونى، سامانه شناختى و ذهن، يردازش و تفسير اطلاعات، ارسال به سامانهاى عصبى و مغز، ارسال بيامهاى عصبى به اندامهاى كفتارى، توليد صوت و بايان يكك مرحله يا شروع واكويه هاى كفتارى

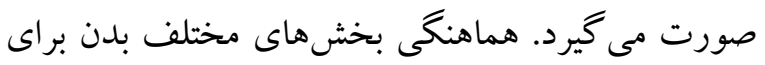
كفتار نياز است و اين هماهنكى توسط ذهن صورت مى گيرد. در حالت عادى يك فرد بايد آنقدر تمرين كند (برنامه ذهنى بسازد) تا به برنامه اصلى دست يابد و از آن جا كه اين اتفاقات در بخش خودكار ذهن شكل

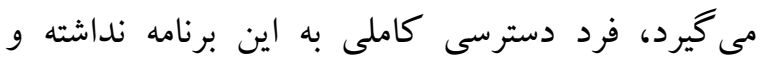

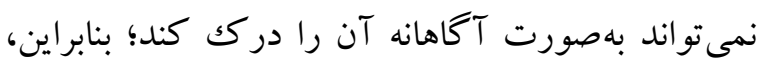
بسيار دشوار است كه بتواند نواقص برنامه خود را بيدا

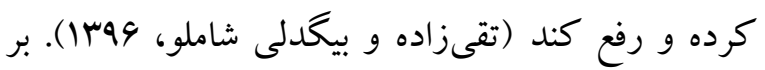
اساس مدل شبيهسازى ذهن، انسان مانند كامييوتر دو بعد 
كسترش خلاقيتهاى ذهنى، باعث توسعه و يِشرفت در كفتار او شد در آخر، بايد اذعان ساخت كه يزوهش حاضر نيز مانند بسيارى از تحقيقات، با محدوديتهاى ويزه خود روبرو بوده است. براى مثال، نمونه بثزوهش حاضر محدود و

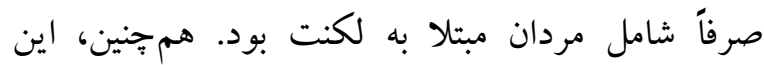
يثزوهش فاقد دورههاى بيخيرى (به منظور بررسى ميزان بايدارى نتايج درمانى) بود. با توجه به محدوديتهاى ذكرشده، بهمنظور فراهم شدن امكان مقايسه نتايج و سنجش ميزان بايدارى اثرات درمانى، بيشنهاد مىشود

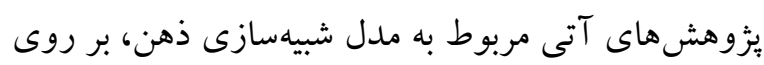

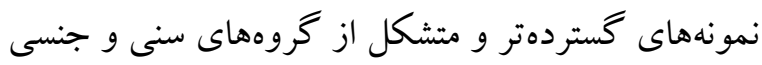
مختلف و با لحاظ نمودن دورههاى بيخيرى انجام شود.

\section{نتيجه كيرى}

يكى از درمانهاى جديد و نويدبخش درى در درمان مؤثر و بدون باز گشت لكنت زبان، مدل شبيهسازى ذهن تقىزاده است. شبيهسازى ذهن يعنى شبيهسازى اطلاعات ذهن و تبديل آن به اطلاعات مادى و فيزيكى كه با مشاهده آن بهوسيله اين دانش نوين مىتوان به اطلاعات ذهن دسترسى بيدا كرد و اكثر تغييرات را بهسرعت در ذهن ايجاد كرد. با توجه به نتايج ئزوشش حاضر و ديخر يثزوهشهاى انجام گرفته در مورد تأثير مدل شبيهسازى ذهن بر اختلال لكنت، مى توان اذعان داشت كه استفاده از اين روش نوين، مى تواند با ايجاد محيطهاى بيبجيده و كسترش خلاقيت هاى ذهنى و در نتيجه توانمندسازى ذهن مبتلايان، درمانكران را در درمان مؤثر و كار آمد اختلال لكنت زبان و مشكلات همراه با آن (مانند مشكلات تجزيهاى در افراد داراى لكنت با سابقه تجارب آسيبزا) در بزر كسالان يارى نمايد.
عمدتاً بر اثر مرگك و تحليل رفتن سلول ها بديد مى آيد. با اين حال، تحقيقات نشان داده اند ذهن با درك واز كان جديد در حال تكامل است و اين تكامل در مغز با رشد و تكامل عصبى يعنى ايجاد سينإِ هاى جديد و توليد سلولهاى عصبى جديد در مغز همراه است. (انرمش عصبى يا نرمش مغزى") اصطلاحى است كه براى توصيف توانايى مغز در بازسازماندهى يا تغيير ارتباطهايش براثر تجربه به كار مىرود. يافته هاى حاصل از يزوهشهاى تجربى حاكى از اين است كه انواع زياد نرمشهاى مغزى (ماند توانايى تحول دندريتها و و تشكيل بيوندهاى سينايسى تازه در اثر تجربه محيطهاى غنى) در تمام دوره بزرگسالى حفظ مىشوند (آذرى و

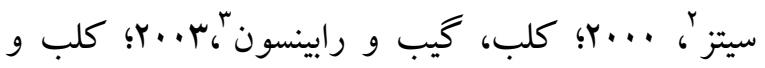

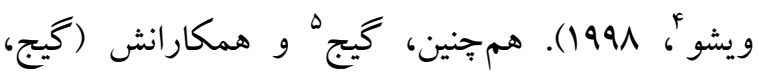

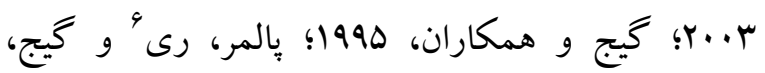
1990) نشان دادهاند كه عصبزايى ^يعنى تولد و رشد نورونهاى نو در بخشهايى از مغز بسيارى از حيوانها و

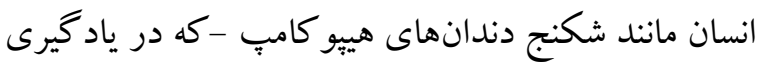
و حافظه نقش دارند- تا بزرگسالى اتفاق مىافتد. همان گونه كه بيشتر اشاره شد، تقىزاده و همكارانش نيز در يزوهشهاى مختلفى با به كار گيرى مدل شبيهسازى هول ذهن نشان دادهاند انسان موجودى منعطف و قابل تغيير و توسعه است و بهجز مواردى كه مغز و بدن دجار آسيبهاى جدى شدهاند، محدوديتى براى رشد انسان وجود ندارد و مىتوان با ايجاد محيطهاى بيبجيده و

\footnotetext{
1- Brain plasticity or neuroplasticity

2- Azari \& Seitz

3- Kolb, Gibb \& Robinson

4. Whishaw

5 - Gage

6- Palmer, \& Ray

7. Neuron genesis
} 
Payame- Noor University. Tehran Jonoob branch (In Persian)

Debashi L, Najafi M \& Rahimian-Boogar I. (2018). The Effectiveness of Cognitive- Analytic Therapy on Impulsivity and Dissociative Experiences of Borderline Personality Disordered Patients. Clinical Psychology, 10(2), 14-27.(In Persian)

Delavar A. (2012). Educational and Psychological Research, 4th rivised. Tehran: Virayesh Publication Institute.

Doneva S, Davis S \& Cavenagh P. (2018). Comparing the performance of people who stutter and people who do not stutter on the Test of Everyday Attention. Journal of clinical and experimental neuropsychology, 40(6), 544-558.

Farazi M, Gholami Tehrani L, Khodabakhshi Kolaee A, Shemshadi H \& Rahgozar M. (2014). The effect of a combination of cognitive therapy and speech in stutterers. Thought \& Behavior in Clinical Psychology, 8(30), 37-46. (In Persian)

Gage FH, Coates PW, Palmer TD, Kuhn HG, Fisher LJ, Suhonen JO, ... \& Ray J. (1995). Survival and differentiation of adult neuronal progenitor cells transplanted to the adult brain. Proceedings of the National Academy of Sciences, 92(25), 11879-11883.

Gage FH. (2003). Brain, repair yourself. Scientific American, 289(3), 46-53.

Guitar B. (2006). Stuttering: an integreted approach to its nature and treatment. $3^{\text {td }}$ ed. Publication: lippincott Williams and Wilkins publ.

Hashemian MA, Agha-Mohammadian SH \& Mashhadi A.(2017). Effectiveness of Eye Movement Desensitization and Reprocessing (EMDR) to Reduce the Severity of Symptoms of Post-Traumatic Stress Disorder and Stuttering With Psychological Origin (Case Study in Child with Four Years Old). Arak Medical University Joumal (AMUJ), 19 (11), 87-98. (In Persian)

Iverach L, Jones M, McLellan LF, Lyneham HJ, Menzies RG, Onslow M, Rapee RM. (2016). Prevalence of anxiety disorders among children who stutter. Joumal of Fluency Disorders, 49, 13-28.

Jacques S \& Zelazo PD. (2005). On the possible roots of cognitive flexibility.

Kakoee F, Arani- Kashani Z, Kamali M \& Jan Bozorgi M. (2016). Social phobia and its relation to demographic characteristics in adults with stuttering disorder. Iranian Joumal of Psychiatric and Clinical Psychology, 21 (4), 362-369. (In Persian)

Kempermann G, Gast D, Kronenberg G, Yamaguchi M \& Gage FH. (2003). Early determination and long-term

$$
\begin{aligned}
& \text { سياسگز ارى }
\end{aligned}
$$

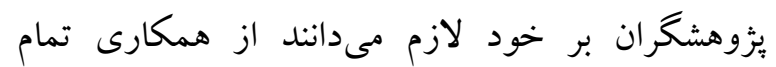

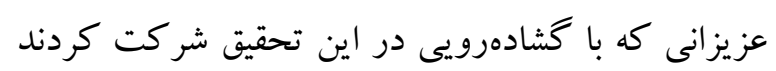

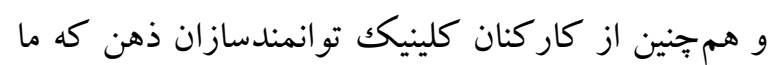

$$
\begin{aligned}
& \text { را در اجر ایى اين يزوهش يارى رساندند، صميمانه تشكر و } \\
& \text { سياسگز ارى نمايند. }
\end{aligned}
$$

\section{References}

Ahadi B, Sotoodeh MB \& Habibi Y. (2013). Comparing psychological well-being and defense mechanisms in students with and without stuttering. Journal of school psychology, 1 (4), 6-22. (In Persian)

American Psychiatric Association. (2013). Diagnostic and Statistical Manual of Mental Disorders (DSM-5). Translated by Rezaee. F. and other (2015). Tehran: Arjmand publication. (In Persian)

Amrollahi S, Moradi AR \& Hasani J. (2016). Effectiveness of Memory Specificity Training for Cognitive Vulnerability and Dissociative Experiences in Patients with Post traumatic stress Disorder. Journal of Cognitive Psychology, Vol. 4, No. 3, 35-44. (In Persian)

Azari NP \& Seitz RJ. (2000). Brain Plasticity and Recovery from Stroke: What has changed in the brain of a stroke patient who recovers the ability to move a once-disabled limb?.American Scientist, 88 (5), 426431.

Behrozi N, Shahni Yeylagh M \& Pour Saeed SM. (2013). The relationship of perfectionism, perceived stress and social support with academic burnout. Strategy of culture, 5(20), 83-102.(In Persian)

Bernstein E, PutnamFW, Ross CA, Torem M, Coons P, Dill D, ... \& Braun BG. (1993). Validity of the Dissociative Experiences Scale in screening for multiple personality disorder: A multicenter study. AmJ Psychiatry, 150, 1030-1036.

Bijleveld HA. (2015). Post-traumatic stress disorder and stuttering: a diagnostic challenge in a case study. Procedia-Social and Behavioral Sciences, 193,37-43.

Dadgar P \& Taghizadeh ME. (2020). An investigation the effectiveness of the simulation mind model on future expectancy and reducing hopelessness in adult with stuttering disorder. Master's Thesis, 
persistence of adult-generated new neurons in the hippocampus of mice. Development, 130(2), 391399.

Khalili SF, Pakdaman S \& Saleh SB. (2009). The effect of simple and both process and product mental simulation on academic performance of ordinary and gifted students. Educational and Psychological Joumal, 5(1), 23-42. (In Persian)

Khandan Z, Taghizadeh ME. (2018). The study of the effectiveness of mind simulation model on reducing social anxiety and increasing the resilience of stutterers with a range of 20-40 years of age. Master's Thesis, Payame- Noor University. Tehran Jonoob branch (In Persian)

Kolb B \& Whishaw IQ. (1998). Brain plasticity and behavior. Annual review of psychology, 49(1), $43-64$.

Kolb B, Gibb R \& Robinson TE. (2003). Brain plasticity and behavior.Cument Directions in Psychological Science, 12(1), 1-5.

Palmer TD, Ray J \& Gage FH. (1995). FGF-2-responsive neuronal progenitors reside in proliferative and quiescent regions of the adult rodent brain. Molecular and Cellular Neuroscience, 6(5), 474-486.

Parsa A, Dortaj F \& Salehzadeh KS. (2011). Investigation the effect of process, product and mixed mental simulation on memory and academic performance improvement in high school students. The first national conference on cognitive science in education and training. (In Persian)

Sajadi SF \& Dehghanizadeh Z. (2016). A survey on the relationship between alexithymia and dissociation experiences with eating attitudes in girl students of Shahid Chamran University of Ahwaz. Journal of Shahrekord Univ Sci of Medical science; 18 (5): 8-17. (In Persian)

Sanei N \& Taghizadeh ME. (2017). The study of effectiveness of mind simulation model on emotion regulation and positive thinking in 20-40 years old people with stuttering disorder. Master's Thesis, Payame- Noor University. Behshahr branch (In Persian)

Shir- Khodaee Z \& Taghizadeh ME. (2017). The study of effectiveness of mind simulation model on reduce the fear of verbal communication and self- confidence enforcement in 20-30 years old men with stuttering disorder. Master's Thesis, Azad Islamic University, Tehran branch. (In Persian)

Taghizadeh ME \& Bigdeli SM. (2016). The Effectiveness of Stuttering Therapy Using Mind Simulation. 3th International Conference on Recent Innovations in
Psychology, Counseling and Behavioral Sciences, Tehran: Iran. PSYCHO03_285. (In Persian)

Taghizadeh ME \& Bigdeli SM. (2017). Speech Algorithm and Speech Creativity in Human. 4th Intemational Conference on Recent innovations in psychology, counseling and behavioral sciences. (In Persian)

Taghizadeh ME \& Bigdeli SM. (2017). The role of coding and programming of mind in controlling and changing the brain and body. 4th Intemational Conference on Recent innovations in psychology, counseling and behavioral sciences. (In Persian)

Taghizadeh ME, Yarollahi NA \& Bahrami Z. (2018). Investigation the effectiveness of the mind simulation model on reducing stress and increasing cognitive flexibility in adult with stuttering disorder. Shenakht Joumal of Psychology and Psychiatry. Vol. 5/ No. 2, 67-80. (In Persian)

Toozandehjani H, Naaimi H, Ahmadpoor M. (2011). An investigation on the efficacy of confrontation cognitive-behavioral skills through group training on the anxiety and adjustment of children with stuttering. Research in rehabilitation science, 7 (2) 126-140. (In Persian)

Woodward J, Carmine D \& Germen R. (1998). Teaching problem solving through computer simulations. American educational research journal, $\mathrm{Vol} 25$, No 1, 72-86.

Zamani P \& Latifi SM. (2011). The efficacy of prolonged speech technique in boys with mild stuttering. Journal of Shahrekord University of Medical Sciences, 13(5): 20-26. (In Persian) 